\title{
Alfons Gregori, La dimensión politica de lo irreal. El componente ideológico en la narrativa fantástica española y catalana, Poznań, Uniwersytet Im. Dama Mickiewicza w Poznaniu («Seria Filologia Romańska», 56), 2015, 489 pp. ISBN 978-83-232-2995-7
}

Des del centre del continent europeu, el professor Alfons Gregori, doctor en Literatura Comparada per la Universitat Adam Mickiewicz de Poznań (Polònia) i docent en l'esmentada universitat, ens presenta una exhaustiva obra d'investigació que aborda l'estudi de la narrativa fantàstica catalana i espanyola des de l'òptica ideològica. La trajectòria investigadora de Gregori comprén diverses àrees d'estudi, entre les quals destaquen les que aixopluguen aquest treball, com són la dedicada a l'anàlisi dels aspectes ideològics en la narrativa fantàstica i, col-lateralment, la de l'estudi del compromís en literatura. Part de la seua recerca es canalitza mitjançant el Grupo de Estudios sobre lo Fantástico de la Universitat Autònoma de Barcelona i la revista Brumal. Revista de Investigación sobre lo Fantástico.

Si bé es podria pensar que es tracta d'un manual d'anàlisi literària, en llegir el volum amb deteniment es veu clarament que es tracta d'una obra d'investigació rigorosa que conjuga tant els estudis literaris i la història de la cultura com la filosofia i la psicoanàlisi. Des d'aquesta perspectiva interdisciplinària Gregori configura un estudi innovador pel que fa a diversos aspectes. Metodològicament, es tracta d'una anàlisi interpretativa a la llum d'un cos teòric divers i complex aplicat a un corpus unitari de contes d'especial interés. Contes considerats per l'estudiós com a perifèrics perquè provenen de literatures com la catalana o de zones no centrals de l'espanyola com Lleó o Andalusia, i perquè en alguns casos són fruit d'autors i autores que no han destacat per tindre un paper cabdal en el sistema literari. No obstant la condició perifèrica, la qualitat de les narracions fantàstiques no es veu afectada ja que la tria és resultat d'un rastreig exhaustiu per la literatura catalana i espanyola de finals del s. XIX i l'inici del s. XXI.

La naturalesa acadèmica d'aquest treball en determina l'estructura, la qual consta de tres parts principals: una breu presentació seguida del cos, dividit en una part teòrica i en una altra d'anàlisi literària, i un capítol final que recull les conclusions. Pel que fa al cos central, en la primera part d'aquest i sota el subtítol «Literatura fantástica e ideología: planteamientos teóricos», Gregori basteix un ampli aparat crític amb l'objectiu, d'una banda, de delimitar les diferents etiquetes terminològiques que giren al voltant dels estudis del fantàstic, i d'altra, d'aproximar-se al concepte d'ideologia per a després aplicar-lo als textos literaris. L'interés d'aquest volum radica en la voluntat d'establir una sistematització de les diferents teories del fantàstic, tot 
identificant les peculiaritats de cadascun d'aquests gèneres i subgèneres, entre els quals hi ha el meravellós, la ciència-ficció o el fantasy. S'hi prenen com a punt de partida els plantejaments estructuralistes del gènere fantàstic de Tzvetan Todorov i les rèpliques posteriors, com la d'Irène Bessière, que no considera el fantàstic com a gènere literari. A més de les provinents de la psicoanàlisi d'inspiració feminista i dels plantejaments postmarxistes de la mà de Rosemary Jackson i de José B. Monleón. Aquest últim, des d'un enfocament sociocultural, estableix clars lligams entre el fantàstic i la història i la manera en què ambdós es produeixen i canvien amb el pas del temps i de les condicions. En últim terme, s'arriba a Rachel Bouvet i David Roas, estudiosos ambdós que des del marc de la Teoria de la Recepció proposen que el text fantàstic provoca determinades emocions en el públic lector pel que té d'inexplicat i el paper que hi juga aquest en el procés de construcció del significat del text. Així, Alfons Gregori estructura un panorama crític de les teories del fantàstic des de la dècada dels setanta ençà per establir amb claredat un seguit de conceptes que seran aplicats en la part analítica de l'obra, com ara la diferència entre fantàstic i meravellós, l'inexplicat i l'inexplicable, l'ominós, etc.

Si una part destaca, però, per la seua naturalesa interdisciplinària i crítica és la dedicada a les relacions entre les teories del fantàstic i les ideologies que les recorren de manera subjacent. L'autor fa una lúcida reflexió sobre la tendència a atribuir a la literatura fantàstica propensió cap a l'escapisme i a defugir les problemàtiques del món anomenat «real». És possiblement aquest etiquetatge erroni el que impulsa a gratar les fines capes ideològiques que cobreixen els contes que Gregori explora en aquest estudi. En aquesta línia, s'hi realitza un seguit d'apreciacions sobre el condicionament que el context cultural, històric i social exerceix sobre la literatura, i com es reflecteix estèticament en les obres des dels principis formalistes fins als del realisme socialista.

Arribat aquest punt, Gregori enllaça amb mestria la segona secció argumentativa pel que fa al concepte d'ideologia i l'adequació d'aquest als estudis literaris. L'autor defensa la idoneïtat d'aquest concepte com a categoria analítica a pesar de les crítiques que li han adreçat grans veus de l'acadèmia contemporània com Michel Foucault $o$ Daniel Bell, que el consideraven poc encertat. Gregori refâ el concepte de les crítiques adduïdes i el reorienta com a categoria d'anàlisi eficaç dins el camp de la teoria de la literatura i de la literatura comparada. Per tant, veurem com l'investigador s'enfronta al concepte d'ideologia, i en certa manera al d'art, des d'una concepció teòrica com la que possibilita la filosofia i la teoria de la literatura amb les referències de crítics i pensadors marxistes i postmarxistes en l'esfera política i en l'esfera dels estudis estètics. En les encertades paraules de Gregori, es treballarà «acerca del componente ideológico en la literatura fantástica, y no lo meramente político, social, cultural o religioso» (2015: 133). 
La segona part, «Lo ideológico en la narrativa fantástica española y catalana: un análisis», se centra a aplicar el concepte d'ideologia, i d'altres d'adjacents, als dènou relats seleccionats per l'autor. Aquesta segona part respon, si fa no fa, a les esperances dels ulls filològics que cerquen una panoràmica clara i concisa de peces clau de la narrativa fantàstica espanyola i catalana contemporània, sempre que es tinga en consideració l'orientació comparatista de la tria. L'anàlisi literària realitzada per Gregori, marcada pels procediments metodològics de la literatura comparada, resumeix l'argument dels relats per a imbricar-hi les pistes interpretatives provinents de l'aparat crític sobre les diferents ideologies que creuen aquests textos. En afirmar l'autor que la ideologia forma part de la realitat $\mathrm{i}$, per tant, que és susceptible de formar part de la representació que la literatura en fa, bé siga en clau mimètica o no, aquesta noció esdevé el germen de la investigació literària i així bé s'hi observa.

Amb aquest procediment, s'explora la base ideològica de les narracions amb l'objectiu d'identificar els principis del conservadorisme, el liberalisme, l'anarquisme, el socialisme, el nacionalisme o el feminisme que puga subjaure en cadascuna de les narracions. Perquè siga possible aquesta recerca, l'investigador té en compte el bressol ideologicopolític dels autors, les autores i de l'època de producció dels relats. Però, malgrat açò, la matèria d'estudi no és altra que, afortunadament, el text literari i els significats que se'n desprenen, cosa que provoca una immersió en les línies interpretatives proposades i en el material literari seleccionat.

Cronològicament, els relats escollits per Gregori corresponen a un ampli període històric que abraça des del tombant del s. XIX a la primera quinzena del XXI, encara que hi ha una quantitat major d'aquells adscrits als segles posteriors. A pesar d'aquest cert desequilibri, les peces de tots els períodes són representatives de les estètiques d'aleshores i donen bona mostra de les inquietuds artístiques i ideològiques de les èpoques respectives. Encara que fem referència a la cronologia de les obres, per mostrar el gran abast del treball, el criteri per a classificar-les no respon a l'historicista sinó a una equilibrada tríada temàtica segons el fenomen preternatural que hi té lloc: el doble, els objectes amb poders preternaturals i d'altres fenòmens fantàstics.

En el recull es conjuguen narracions escrites en català i en castellà que apleguen noms com els de Maria Aurèlia Capmany, Albert Sánchez Pińol, Pere Calders, Maria Antònia Oliver o Joan Perucho i Emilia Pardo Bazán, Jose Ma Merino, Álvaro Cunqueiro o la guardonada Cristina Fernández Cubas, per fer esment d'algunes de les figures. Per bé que la diversitat del corpus és rellevant en alguns aspectes, no podem obviar que d'un total de dènou relats tan sols quatre són creació d'escriptores. Al llarg de l'estudi es posen de manifest els criteris d'elecció dels textos però no s'hi explicita la causa de la poca presència femenina en aquesta anàlisi. Ens hauríem de preguntar, 
doncs, si aquesta mancança és deguda a l'absència de creació fantàstica per part de dones o, si s'explica perquè el cànon de la literatura de l'irreal encara resta incomplet i no les hi ha incloses.

Quant a l'anàlisi literària d'aquest corpus trobem lectures a la llum de la crítica del component ideològic de les quals en destacarem un nombre reduït per l'agudesa interpretativa de què gaudeixen i amb l'objectiu d'il.lustrar-ne la diversitat.

Del bloc referent al fenomen del doble, són les indagacions realitzades sobre la narració «En el hemisferio sur», de Cristina Fernández Cubas, i sobre «O ell, o jo», de Pere Calders, algunes de les més reeixides, encara que tota la secció d'anàlisi és digna de lectura per a un públic interessat en la lectura ideològica del fantàstic. Podem fixar-nos en el primer cas, on l'autor ens presenta una anàlisi detallada d'un relat complex tant per contingut, com per forma ja que es tracta d'un joc metaliterari on els personatges d'un editor frustrat i d'una turmentada escriptora provoquen una confusa situació a causa de la suposada presència de dobles. En aquest relat, Gregori posa en funcionament les teories d'anàlisi sobre l'alteritat i la construcció del fantàstic en els diversos nivells de realitat entre dos personatges oposats en gènere i actitud vital però alhora amb fronteres desdibuixades entre ells a causa del vincle amb la literatura, i la metaliteratura. Una anàlisi que va més enllà de les premisses de la crítica feminista, de la qual participa, ja que esmenta la construcció de gèneres, les possibles lectures sobre el paper de la dona i la sexualització del poder, i que enllaça amb el dubte del real i l'irreal propi del gènere fantàstic.

En el bloc dedicat als objectes amb poders preternaturals, destaquem les interpretacions crítiques de "La esfera prodigiosa», de Luis Valera, i «La veu de Madame Ricard", del modernista Diego Ruiz. En aquests casos, Gregori s'acosta als plantejaments de la crítica postcolonial per a desentortolligar les identitats que s'imbriquen en dos relats lligats a terres estrangeres. És, sens dubte, el relat de Valera el que se centra a explotar el tòpic de l'exotisme d'Orient mitjançant un misteri relacionat amb el budisme i un fet estrany en una de les seues figures sagrades, una escultura de Buda. En aquest sentit, Gregori remarca els prejudicis de què va carregada la narració i els rols de colonitzadors i colonitzats atribuïts als personatges amb l'objectiu d'il.lustrar com es menystenia, s'exotitzava i efeminava tot l'univers de creences orientals. En «La veu de Madame Ricard», el procediment d'anàlisi aplicat per l'autor s'allunya dels postulats postcolonials. Encara que hi són presents de manera col-lateral perquè es tracta d'un relat situat a Orà on les protagonistes són dues joves italianes i una dona francesa d'edat avançada, que fa de dic de contenció de les influències algerianes. L'autor posa el focus en l'aparició de l'esperit de Ricard a través d'unes monedes 
des del concepte freudià del sinistre i la relaciona amb la crítica marxista pel que fa a l'obsessió de l'anciana per l'acumulació.

En darrer lloc, hi ha els relats amb presència d'altres fenòmens fantàstics i hi destaquem l'anàlisi d' "Avís misteriós», de Joaquim Ruyra i de «M'han florit ametllers a les butxaques", de Maria Antònia Oliver. Pel que fa al relat de Ruyra, Gregori dissecciona les relacions del fantàstic sobrenatural d'aquesta narració amb l'ideari catòlic de l'autor gironí sobre la presència d'un somni premonitori sobre la mort de la mare. Unir la figura materna, el destí diví i el lligam amb la terra i la naturalesa en la concepció primigènia de la catalanitat d'inicis de segle xx és el que aconsegueix l'autor en aquesta anàlisi que posa en joc religió i política. L'última reflexió és al voltant de «M'han florit ametllers a les butxaques», que és qualificada per Gregori com una narració amb trets bàsics de la novel-la postapocalíptica i distòpica en crear una situació de destrucció total de l'illa de Mallorca a causa de la proliferació d'hotels i urbanitzacions. El turisme, responsable de tots els mals, dilapida l'illa mentre la població alienada i confusa arran dels efectes crematístics positius no hi fa res fins al punt de la desaparició de la vida humana i animal de l'indret. Aquesta recreació, amb ingredients del fantàstic, porta l'investigador a rastrejar el concepte d'ideologia des de la perspectiva marxista, com a «mistificación que ofusca a las clases populares acerca de los verdaderos engranajes de la economía» (2015: 409) i a revisar les idees ecologistes que suren al relat.

Tot plegat, tenim entre mans un volum no apte per a qui s'inicie en els estudis del fantàstic però que, per contra, esdevé d'obligada consulta per a qui investigue en literatura i s'interesse per noves perspectives d'anàlisi i metodologies interdisciplinàries. Com també per a qui desitge aprofundir en un tema controvertit com és el de la presència de la ideologia en la producció fantàstica. Aquest treball ompli un buit en la crítica literària estatal i aporta llum sobre la configuració del fantàstic i del conreu d'aquest gènere a casa nostra i a la literatura veïna. Com bé apunta l'autor, no abunden els estudis sobre literatura fantàstica a l'Estat espanyol a conseqüència de la tímida publicació d'obres d'aquest gènere, si més no fins a les primeries dels 2000 . La propensió cap a la literatura d'estètica realista, en els àmbits català i espanyol, ha creat una situació anàloga en els dos casos. Malgrat tot, i a excepció d'un grapat de veus, no ha sigut fins fa ben poc que el fantàstic ha alçat el vol, tant en producció com en el territori de la crítica gràcies a aportacions com la d'Alfons Gregori.

Irene Mira

Universitat d'Alacant irene.mira@ua.es 